\title{
Audiovisual English-Arabic Translation: De Beaugrande's Perspective
}

\author{
Alaa Eddin Hussain (Corresponding author) \\ Department of Translation Studies, Effat University, Saudi Arabia \\ E-mail: alaeddinhussain1@gmail.com \\ Ahmad Khuddro \\ Department of Translation Studies, Effat University, Saudi Arabia \\ E-mail: akhuddro@effatuniversity.edu.sa
}

$\begin{array}{lll}\text { Received: 18-12-2015 } & \text { Accepted: 28-02-2016 } & \text { Advance Access Published: March 2016 } \\ \text { Published: 01-05-2016 } & \text { doi:10.7575/aiac.ijalel.v.5n.3p.212 } & \text { URL: http://dx.doi.org/10.7575/aiac.ijalel.v.5n.3p.212 }\end{array}$

\begin{abstract}
This paper attempts to demonstrate the significance of the seven standards of textuality with special application to audiovisual English Arabic translation. Ample and thoroughly analysed examples have been provided to help in audiovisual English-Arabic translation decision-making. A text is meaningful if and only if it carries meaning and knowledge to its audience, and is optimally activatable, recoverable and accessible. The same is equally applicable to audiovisual translation (AVT). The latter should also carry knowledge which can be easily accessed by the TL audience, and be processed with least energy and time, i.e. achieving the utmost level of efficiency. Communication occurs only when that text is coherent, with continuity of senses and concepts that are appropriately linked. Coherence of a text will be achieved when all aspects of cohesive devices are well accounted for pragmatically. This combined with a good amount of psycholinguistic element will provide a text with optimal communicative value. Non-text is certainly devoid of such components and ultimately non-communicative. Communicative knowledge can be classified into three categories: determinate knowledge, typical knowledge and accidental knowledge. To create dramatic suspense and the element of surprise, the text in AV environment, as in any dialogue, often carries accidental knowledge. This unusual knowledge aims to make AV material interesting in the eyes of its audience. That cognitive environment is enhanced by an adequate employment of material (picture and sound), and helps to recover sense in the text. Hence, the premise of this paper is the application of certain aspects of these standards to AV texts taken from various recent feature films and documentaries, in order to facilitate the translating process and produce a final appropriate product.
\end{abstract}

Keywords: Arabic audiovisual translation, coherence, cohesion, textuality

\section{Text linguistics analysis overview}

Different approaches to study texts linguistically have been suggested, e.g. text grammar (Van Dijk, 1972), text linguistics (de Beaugrande \& Dressler, 1981) and discourse analysis (Brown \& Yule, 1983; Schiffrin, 1984). These different and sometimes rather incompatible methods give rise to think that it is rather difficult to employ a single approach in particular in studying and analyzing texts adequately. At the outset it is important to highlight the basic differences between various terms and jargons used in these methods. A text grammar (cf. Van Dijk), for example, attempts to map a model which provides an adequate and consistent model for syntax. This model largely overlaps with Chomsky's transformational approach. Text linguistics of de Beaugrande and Dressler, Carstens (1978) is devoted to pinpoint how texts are created and comprehended. Donnelly (1994, p.18), for instance, paid special attention to the properties of text, i.e. what constitutes their textuality or texture. Discourse analysis of Schiffrin 1984 traditionally entails the analysis of chiefly written texts, especially the analysis of utterances as social interaction. Schiffrin (p.419) fails short of providing a definition for discourse analysis. This is due to the fact that he merely states that discourse analysis "is one of the most vast, but also least defined areas in linguistics" (p.42). De Beaugrande and Dressler's approach to text linguistics 1981, however, was favoured by many text linguists because of its appropriate definition of text linguistics, which is defined as a communicative occurrence that needs the seven standards of textuality mentioned by these two authors. These seven standards rename as principles refer to a cohesion, coherence, intentionality, acceptability, informativity, contextuality and intertextuality (1995, p.3).

Cohesion deals with the ways in which components of the sentences of a text, the words we actually hear and use, are mutually connected grammatically and lexically. Halliday and Hasan (1976, p.11) defines cohesion as grammatical and lexical devices. Cohesion exists where "interpretation of any item in the discourse requires making reference to some other item[s] in the discourse". According to de Beaugrande and Dressler, surface components depend upon each other according to grammatical forms and conventions such that cohesion rests upon grammatical dependencies. This entails that the syntactic knowledge of a language user plays an important part in constructing these relations. Jackson (1991, 
p.252) refers to the fact that "a bond is formed between one sentence and another because the interpretation of a sentence, either depends on or is informed by some item usually in a previous sentence". Halliday and Hasan (1976, p.8) consider this relation to be "of a semantic nature" and that in cohesion there is a semantic relation between one item and another in a text, alongside some other item which is vital to its interpretation. The two items of a text, which can be described "the presupposing and the presupposed", could or could not be structurally connected to one another. But that still keeps to the meaning of cohesion relation. Halliday and Hasan in Cohesion in English (1976, p.13) generally accept these linguistic devices as "the essential semantic relations whereby any passage of speech or writing is enabled to function as text" governed by five distinct different categories. These are represented in the text by particular features, repetitions, omissions, occurrences and constructions. These categories which cement the textuality of the texts are reference, substitution, ellipsis, conjunction and lexical cohesion. Reference denotes the introduction of a new item in the text, and the subsequent referral to that same item by means of another item. Normally it refers to pro-form. The effect of reference lies in the retrieval of information from somewhere else in the sentence or in a neighboring sentence by using one of the grammatical devices mentioned above. Substitution, on the other hand, is used in the place of another word or phrase to prevent repetition of the same word or phrase, this enables the text to be shortened. There are different types of substitutions, e.g. nominal, verbal and clausal (1976, p.31). Elements in sentences can be physically deleted because the writer thinks that the receptor is competently aware of inserting the deleted elements in his/her own sentence (Donnelly 1994, p.103). Needless to emphasize, the receptor has to listen carefully to establish cohesive links. Three kinds of ellipsis can be identified, and these are nominal, verbal and clausal. Conjunction and adverbs are used to connect propositions in surrounding sentences depending on certain semantic relations, conjunctions such as additive, adversative, causal and temporal. Conjunctive elements serve to reenforce and highlight their relationship between other elements of the text (Donnelly, p.105). The selection of a particular conjunctive marker provides the reader with the clues as to how the writer receives the statements to be related, how he/she thinks the reader should understand the text.

Cohesive lexical relations are synonymy, antonymy, collocation, and hyponymy/hyperonymy (created by specific lexical items) to name a few. Semantic knowledge of the discourse is necessary to determine the acceptance and nonacceptance of a text. Throughout this paper it has been emphasized that coherence is the most significant element of the text without which a text will be senseless and non-sensical. However, it is rather difficult to establish what makes a text coherent. Neubert and Shreve (1992, p.94), however come up with a useful definition. A coherent text should show logical sequence its overall structure which can then guide the receptor throughout the whole text. Within the same context, Mulder and Hervey (The strategy of Linguistics, 1980, p.32) define it as the underlying logical structures among the immediate constituents of the text that guide the reader throughout the text so that it sticks together as a unit (Hatch 1992, p.209), and provide the impression that the text holds up together in order to make sense and not just be disconnected sentences (McCarthy 1991, p.26).

Intentionality and acceptability are two factors involved in the translation as process and translation as product. To achieve a successful communicative relevance, both producers and addressees have to adhere to the pragmatic cooperative principles which can be outlined as that one has to make the maximum effort to enable a piece of knowledge to be communicated successfully. Pragmatic contextual knowledge shared by participants determines the optimal relevance of communication. This is applicable in pragmatics and socio-linguistics.

Contextuality is very much dependent on adequate knowledge of socio-linguistics and pragmatics; while intertextuality has to do with the experience of the previous text (literary and non-literally). Therefore, coherence is an umbrella device for all these aspects; this combined with a good amount of psycholinguistics, is an essential factor to understand the communicative value of a text.

An attempt has been proposed in this paper to demonstrate the pragmatic application of these principles in the audiovisual environment, and it has been highlighted that knowledge of the different polylinguistic subsystems can be more effective in laying down the foundations of audiovisual translation as a means of communication, in which the principles of textuality play an integral part to improve the interrelation between the study of language and translation. We do trust that we have succeeded in the implementation of some of these devices as suggested by de Beaugrande adequately and consistently in English-Arabic AVT.

\section{Audiovisual bird's eye view}

\subsection{Introduction}

In all audiovisual material, actors/characters take the roles of text producers and text receivers alternately. Each character in each occurrence or event assumes the role of text user: either as text producer when speaking or text receiver when listening. Also, the intention or attitude of the text producer as well as that of the text receiver need to be identified; identifying these two attitudes makes the text communicative. These attitudes are related to de Beaugrande's standards of intentionality and acceptability respectively and successively. There are elements related to cohesion which need to be identified too. Its cohesive devices used to produce long-range stretches of text common in audiovisual environment and need to be identified in order to fulfill optimal benefit when they make the text highly communicative in the eyes of the viewer.

Audiovisual scripts are divided mainly into subtitling and dubbing (including lip-synchrony and isochrony) with subdivisions such as links, voice overs, and soundbites or the last two also known as voice-overing. The common variant forms in the audiovisual domain are: 
1. Audio-to-audio forms: The client provides the audiovisual translator with an audio file in the SL and expects the product to be an audio file in the TL. Here the task of the audiovisual translator is particularly hard, as the translator needs to listen carefully to the SL audio, and translate immediately into the TL as the ST is not provided here. The TT should be recordable as a target audio file, as in the case of translating a source voiceover/dubbing material in its audio form to be a target script that is appropriate for recording in a voice-over and/or dubbing booth.

2. Visual-to-visual forms or written to written forms as in subtitling and captions that appear on screen: The client usually provides a transcript along with the video or dvd and expects to get back a subtitled file in the TL. ${ }^{1}$ That is when there are SL subtitles or captions like road signs and names of shops appearing on the screen and need to be translated in the TT in such a way that they will fit on the screen. Here the number of TL characters (like letters, spaces and punctuations) on the television screen needs to be counted in order to fit. The yardstick currently used by various subtitling companies in the UK with regard to European languages is about 38 to 39 characters per line of a subtitle (this is confirmed by Jorge Diaz-Cintas who has indicated in Durham Conference papers presented in September 2007 in the beautiful historical city of Durham) whilst it is 42 characters per line with regard to Arabic and Hebrew.

3. Audio-to-visual forms or verbal to written forms as in translating an audio in the SL into a subtitled file in the TL.

4. And finally visual-to-audio variation or written to oral form as in the case of translating a subtitled file in the SL into a dubbed script in the TL.

\section{2 Factors in audiovisual translation (AVT)}

Now having established what AVT is with all its variations, it is time to know the factors that shackle the mind of the translator in this domain. First and foremost, the translator needs to be aware of the audiovisual environment and have some knowledge about it. It is commonly known that this field is still relatively young, due to the fact that its production relies heavily on technology; and its technology has only been introduced about a century ago with the introduction of silent movies and their intertitles, and the theatre with its surtitles. A limited amount of research is done in the field of AVT, particularly in the Arab world. (See Muhammad Y. Gamal, May 2008; Tammam Al-Kadi, September 2007) The cinema industry itself was not introduced to the Arab world till mid-forties of the last century and the BBC television was established in mid-thirties of the last century as well; but television reached the Arab world only in late sixties.

The output in AVT needs to reflect not only the translator's linguistic and cognitive knowledge, but also show that the translator is definitely aware of the common forms in AVT (audio-to-audio, visual-to-visual, visual-to-audio, visual-toaudio). The output should also show that the translator has the technical skills, not only how to operate subtitling software and/or do voice-over recordings as well as dubbing takes, but also to identify factors in AV that affect and sometimes restrict the translator during the production of AVT. These factors are related to how the conventional AV script (voice-over script) in the source text (ST) is split into three parts: Time-codes, visual description and audio script (which is the source language text). For a start, it is vital for the translator to know whether the TT is to be voiced over (or dubbed in the form of takes) as narration and commentary, or be recorded as sound-bites (a well-known term in film and television industry). Dubbing has more restraints relating to lip-synchrony (matching the translated words with the movements of actors' lips) and isochrony (matching the ST dialogue with the TT dialogue), see Chaume 2010.

Unlike other forms of translation, AVT is still relatively young in translation studies, and more so in Arabic translation studies. In fact it is still in its infancy in the Arab world in particular. AVT for television into Arabic/English has started to develop seriously in the past two decades, due to the mushrooming of Arabic-speaking satellite television channels - starting with the first pan-Arab satellite television station broadcasting from London, Middle East Broadcasting Centre (MBC) established in September 1991. So the development of AVT in Arabic has only become popular due to the advance in communication technology.

\section{De Beaugrande's perspective}

A text cannot survive in socio-cultural vacuum, it is motivated and inextricably related to situation of occurrence. In brief, according to de Beaugrande, a text is a situation of occurrence in which knowledge is activated. Functionally, the text is interchangeable in the light of, and with reference to its relevant context, since a text is basically motivated by its situational context to which it relates, this entails that the context is prior to its subsequent text. A text cannot be functional unless it meets seven standards according to de Beaugrande. These standards, renamed as principles by de Beaugrande, refer to cohesion, coherence, intentionality, acceptability, informativity, situationality/contextuality and intertextuality.

Cohesion concerns with the way/s in which the components of the surface text (the actual words we hear or see), are mutually connected within a sequence; cohesion rests upon grammatical dependencies (de Beaugrande 1981, p.3). According to Halliday and Hasan (1976, p.11) cohesion exists where the interpretation of any item of discourse requires making reference to the aim and task of text linguisitcs research which tries to determine which makes a text acceptable and another unacceptable. Reference of a cohesive device means the introduction of a new item in a text followed by a

1 For further details see A. Khuddro, "Subtitling in Arabic", Turjuman, vol.9, April 2000, pp.31-37; "Media Translation, particularly for Television", (in Arabic) Turjuman, vol.6, October 1997, pp. 115-130. The AVT selected examples in this current paper are the outcome of about 25 years accumulated work experience in the field. 
referral to that same item by means of another shorter item such as pronouns, demonstratives or comparatives. The effect of reference lies in the retrievable of information from somewhere else in the text. Cohesion relies on the continuity of reference, according to Halliday \& Hasan 1976, p.71), whereby the same content enters into a shorter second items in the discourse. In the process of ellipsis items in sentences are deleted because the author thinks that the receptor on his/her own will be able to recover the missing items when receiving these sentences that are full of elliptical items (Donnally 1994, p.103). Here the pressure is on the receptor to make the connection or relation cohesive. One can recognise various types of ellipsis as nominal ellipsis, verbal ellipsis, and clausal ellipsis. Semantic relations can be seen in the use of adverbs and conjunctions which link concepts in adjacent sentences. These conjunctions (such as additive and causal) serve to re-enforce and highlight the relationship between other elements of the text (Donnally 1994, p.105). They provide the receptor with hints as how the author perceives parts of the statement to be connected to each other. Lexical cohesion focuses on semantic relations which appear in the form of antonymy or synonymy for instance, by using certain lexical items. Recognising semantic structures is crucial in order to sense this form of cohesion, even though such cohesion is not mentioned in de Beaugrande's discussion.

De Beaugrande's cohesion as standard of textuality relies on grammatical dependencies, with devices for long-range stretch of text: these devices include partial recurrence, and ellipsis used within phrases, clauses and sentences; and they assist in the formation of long-range stretches of texts. "Each occurrence is instrumental in assessing at least some other occurrences" (de Beaugrande 1981, p.48).

Short-range cohesion is seen in spotting grammatical dependencies between various items in phrases, or sentences. It is a network of 'nodes' connected by links, as de Beaugrande and dressler describe them (p.53). Long-range cohesion concerns the connectivity of stretches of text by using certain cohesive devices such as recurrence (and partial recurrence), parrallelism, paraphrase, ellipsis, pro-forms, tense and aspect, junction and intonations.

Coherence concerns the ways in which the components of the textual world, the configuration of concepts and relations which underlie the surface text, are mutually accessible and relevant (de Baugrande, 1981). In other words, coherent text has an underlying logical structure that acts to guide the reader through the text so that it sticks together as a unit (Hatch 1992, p.209), and creates the feeling that a text hangs together and that it makes sense and is not just a jumble of sentences (McCarthy 1991, p.26) that are grammatically linked.

Intentionality is text user-centred, and the text producer's view to distribute knowledge and capture a goal, where the text user usually tolerates reduced cohesion and/or reduced coherence for the purpose of revealing the text producer's intentions. To fulfill special effect the text producer may deliberately resort to reduce either coherence or cohesion; on occasion, a text producer may deliberately impair coherence for special effect (de Beaugrande 1981, p.114).

Intentionality concerns the text producer's attitude, a cohesive and coherent text instrumental in fulfilling the producer's intentions (de Beaugrande, 1981), e.g. to distribute knowledge or to attain a GOAL specified in a PLAN. "To some degree, cohesion and coherence could themselves be regarded as operational goals without whose attainment other discourse goals may be blocked. However, text users normally exercise TOLERANCE towards products whose conditions of occurrence make it hard to uphold cohesion and coherence altogether" (p.7), notably in casual conversation. The producer intends to present a piece of information to the text receiver. The text producer should exert the maximum effort to make such text communicative and successful in conveying that piece of information.

Acceptability concerns "the text receiver's attitude that the set of occurrences should constitute a cohesive and coherent text having some use or relevant for the receiver" (de Beaugrande 1981, p.7). Pragmatics is essential in understanding the intentionality and acceptability of a text. Informativity has to do with the way in which parts of the text have communicative value and effect, respective within communicative dynamism as well as knowledge of the informativity value of syntactic expressions.

While contextuality concerns the factors which make a text relevant to a situation of occurrence; intertextuality "concerns the factors which make the utilization of one text dependent upon knowledge of one or more previously encountered texts" (de Beaugrande 1981, p.10). So it is the inclusion of a previous text within the current text.

Cohesion, coherence, intentionality, acceptability, informativity, contextuality, intertextuality and sociolinguistics and literary theory are important in understanding a text. It is the premise of this article that determinate, typical and accidental knowledge contribute to comprehension as well as the production of any text; but often the last type of knowledge is the one used audiovisual environment to create suspense and drama; while the other two are used if repeated to create a sense of humour in that environment. So a comprehensive study employing an interdisciplinary approach rather than a single-sided one is more appropriate.

In this paper certain textual features in English-Arabic audiovisual translation have been investigated with special reference to cohesion, intentionality, acceptability and intertextuality.

\section{Application}

In all audiovisual material, actors/characters take the roles of text producers and text receivers alternately. Each character in each occurrence or event assumes the role of text user: either as text producer when speaking or text receiver when listening. Also, the intention or attitude of the text producer as well as that of the text receiver need to be identified; identifying these two attitudes makes the text communicative. These attitudes are related to de Beaugrande's standards of intentionality and acceptability respectively and successively. There are elements related to cohesion which need to be identified too. Its cohesive devices used to produce long-range stretches of text common in 
audiovisual environment need to be identified in order to fulfill optimal benefit when they make the text highly communicative in the eyes of the viewer.

\subsection{The Gift (2015):- sample of audiovisual material}

Due to the limitation of time and space, special attention has been paid to one of the latest audiovisual material The Gift (2015), which can be regarded as a purposeful sample. Its application can be regarded as a model for subtitlers to follow in the production of their work. Here is a synopsis of this film, according to which the seven standards of textuality have been applied in this paper. A couple, Simon and Robyn, have just moved to a new neighbourhood, because Simon the husband has got a new job in his own hometown. While shopping they met the husband's school mate Gordon, and the drama begins when that mate starts to visit them unexpectedly and starts to create problems for them which eventually ruin their lives. Gordon was doing to avenge what Simon did to him during school days, bullying and harassing him.

Cohesion according to this approach yields various textual devices such as, ellipsis (this includes verbs, subjects and clauses), recurrence, and partial recurrence. Also, intentionality and acceptability will be demonstrated, in addition to intertexuality.

\subsubsection{Ellipsis}

This device helps in the shortening of the text, which is a major feature in audiovisuals. When ellipsis occurs in the SL, it is vital that its TL equivalence is not exactly similar and that is due to the problem of ambiguity if kept as is; therefore, a potential solution could be to add an item/word in order to achieve clarity in the TL. There are three to four types of ellipsis encountered in this film; they are: ellipsis of adverb of place, ellipsis of subject, ellipsis of verb, ellipsis of predicate, ellipsis of part of a verb phrase.

\subsubsection{Ellipsis of adverb of place, e.g.}

\begin{tabular}{|c|c|}
\hline [1] ST: & TT: \\
\hline -So you guys are from Chicago? & ـ أنتما إذن من شيكاغو؟ \\
\hline -Uh, my wife is. & زوجتي من هناك. \\
\hline
\end{tabular}

Here is the addition of the adverb of place 'from there' meaning 'from Chicago'. So the solution here is to provide a shorter version with the same content.

\subsubsection{Ellipsis of subject is also common in AVT, e.g.}

\begin{tabular}{|c|c|}
\hline [2] ST: & TT: \\
\hline -It's late, isn't it? & ـ ـ تأخر الوقت، صحّ؟ \\
\hline -Yeah, our truck already passed. & ـ ـ نعم، سبق أن غادرت شاحنتنا. \\
\hline Tomorrow work? & الغد مناسب؟ \\
\hline I have a window from, like, 7 to 9 ? & عندي وقت مثلاً من 7 إلى 9؟ \\
\hline Sounds good to me. & هذا يناسبني. \\
\hline
\end{tabular}

The last subtitle above shows that the subject is removed, this is an ellipsis of subject; in the TL the subject needs to be inserted in order to make sense of this subtitle. It is recommended to follow this technique. Here it will be ambiguous to translate the above sentence with the subject missing in the TL, therefore the pointing word 'this' is added in the TT for clarity.

Another interesting example of subject ellipsis is this:

\begin{tabular}{|c|c|}
\hline [3] ST: & TT: \\
\hline $\begin{array}{l}\text {-I had no idea who that guy was. } \\
\text {-Really? }\end{array}$ & ـ ما كنت أعرف هوية ذاك الرجل. \\
\hline $\begin{array}{l}\text {-Yeah. Seemed like a nice guy. } \\
\text {-Yeah. }\end{array}$ & ـ نعم. بدا رجلاً ظريفاً. \\
\hline
\end{tabular}

A further example would also be useful here to emphasize the importance of ellipsis in AVT:

\begin{tabular}{|c|c|}
\hline [4] ST: & TT: \\
\hline $\begin{array}{l}\text { I was pregnant, actually, } \\
\text { last year, in Chicago. }\end{array}$ & السنة الماضية حبلى، في شيكاغو. \\
\hline It wasn't a very happy ending. & لم تكن نهاية الحمل سعيدة. \\
\hline Sent me into a bit of a rough patch. & بعد ها مررت بفترة صعبة قليلاً. \\
\hline
\end{tabular}


I will bore you

with the details another time.
سأخبرك بالتفاصيل المملة

في المرة المقبلة.

Again the subject cannot be removed in the TT, as it would be unclear due to the fact that the previous subject 'it' is not the same. So the solution in the TL is to bring back the subject (the pro-form 'she') and reused it.

4.1.1.3 Also, there is the ellipsis of verb, e.g.

\begin{tabular}{|c|c|}
\hline [5] ST: & TT: \\
\hline But life good, though? & لكن الحياة حلوة، مع ذلك؟ \\
\hline Yeah, my--, you know... & نعم، ف.... لعلمك.... \\
\hline I can't complain. & أكاد لا أنشكو من شيء. \\
\hline -That's great to hear, you know? & ـ عظيم أن أسمع هذا، لعلمك؟ \\
\hline -Yes. & 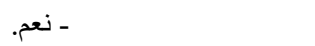 \\
\hline
\end{tabular}

Such ellipsis needs to be written in its full version (recoverable in the form of a full nominal sentence) in the TL in order to avoid ambiguity. One needs to point out the polysemous SL word 'good' in the above two examples and how the TL equivalent in the first example here 'بناسب' is different from the latter 'حلوة', this matter is related to lexical cohesion, how the meaning in each equivalent is totally different to that of the other equivalent.

So the rule for polysemous words such as 'good', 'thing', and 'stuff' is that the translator, subtitler or dubber needs to select the most appropriate and relevant meaning to the word in context, and not to keep one meaning throughout, mistakenly thinking by so doing that such a strategy would help him/her achieve consistency.

\subsubsection{Ellipsis of predicate}

This means to have only the subject of the sentence, whilst its predicate is missing but still recoverable in the SL. An interesting example is this:

\begin{tabular}{|c|c|}
\hline [6] ST: & TT: \\
\hline $\begin{array}{l}\text {-She's beautiful. } \\
\text {-Oh, thank you. }\end{array}$ & - شـ ـ إنهاً للك. \\
\hline What? You are. & ماذا؟ أنت جميلة. \\
\hline
\end{tabular}

Here a potential solution is to repeat the same predicate in the TL and that is due to the fact that the item 'جميلة' [beautiful] has roughly the same number of characters as the word 'كذلك' [so]; otherwise the addition of the word/item 'so' is useful and contributes to the clarity of the TT. De Beaugrande (1981, p.62) cited Priestley saying that "In British English, 'so' is more often omitted in such usage than in American".

\subsubsection{Ellipsis of part of verb phrase}

The skill of the subtitler and/or dubber, even though the dubber needs to shorten the TT even more, is to be able to recover easily the missing part in the ST and put it back in the TT, so long as the number of words/items in Arabic do not exceed those in the ST (this is called in dubbing isochrony - matching the dialogue of the ST with that of the TT), e.g.

\begin{tabular}{|c|c|}
\hline [7] ST: & TT: \\
\hline -Oh, and here you go. & - وخذي هذا. \\
\hline -What is it? Glass cleaner? & - ما هو ؟ منظف زجاج؟ \\
\hline -For cleaning glass. & \\
\hline -Right. & ـ لتتظيف الزجاج. \\
\hline -I saw how much you had. & 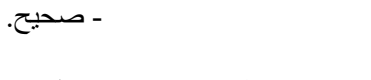 \\
\hline -Yeah. & ـ شاهدت كل الزجاج الذي تنظفينه. \\
\hline
\end{tabular}

Ellipsis as a cohesive device, 'how much glass you had cleaned'. Also partial recurrence is used in 'glass cleaner' and 'cleaning glass', in particular the word 'clean' in its two forms as adjective 'cleaning' and as noun 'cleaner'.

4.2 Pro-verb

Pro-verb is another cohesive device used recurrently in AVT and needs to be taken care of by subtitlers, e.g.

[8] ST: $\quad$ TT:




\section{Did you know}

that Simon was class president?

Oh, yeah. Yeah, I did.

Mr. President.

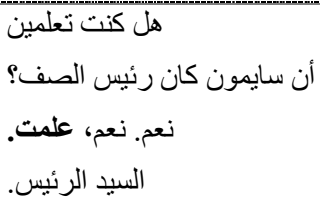

In this example there is ellipsis and substitution at the same time; a potential solution is the one above where the proverb needs to be replaced by the main verb 'know' in the TL, as this cohesive TL solution is to achieve maximum clarity.

4.3 Exophora ('deictics' [pointing words such as 'this' and 'these', and 'that' and 'those] as well as $1^{\text {st }}$ and $2^{\text {nd }}$ person pronouns for instance 'you')

The following example is interesting and fairly complex as it has ellipsis, pro-verb and the deictic word 'this'. In this occasion, Gordon the couple's friend is assumed to have kidnapped the dog. The husband Simon is talking to his wife Robyn about this possibility of kidnapping:

\begin{tabular}{ll}
\hline [9] ST & TT \\
\hline Do you think & لكن هل تعتقدين أنه يقوم بهذ|؟ \\
he would actually do this though? & \\
I mean, take your dog? & \\
\hline
\end{tabular}

The pro verb 'do' and the deictic word 'this' can only be recovered by a skilful subtitler who is capable of looking at the extralingual element which cannot be easily found in the text, but can be realised only when examined in context. Ellipsis as a cohesion device too or even substitution is in the big chunk of the verb phrase 'take the dog', as a cohesive device. Also intentionality and acceptability are touched upon, that is only when the wife wants to clarify ambiguity in her husband's question above, and she says 'you mean...".

With regards to deictics, de Beaugrande (1981, pp.167-68) discussed the issue about the use of 'this'. In our example, the possible solution in the TL is to avoid the polysemous verb 'do' and to use instead a verb such as 'carry out', since the verb 'do' is a pro-verb. With regards to the equivalent of the word 'this', it can be found in the TL but with special care being paid to the gender issue, the masculine 'this' or the feminine one (i.e. هذه or).

Deictics are often used in AVT, and the skill of the subtitler and dubber is in unravelling to what these pointing words are referring. In the following example, the cashier in the supermarket is talking to Simon, the husband:

\begin{tabular}{|c|c|}
\hline [10] ST: & TT: \\
\hline -How was your day today? & ـ كيف كان يو مك؟ \\
\hline -It's good. & 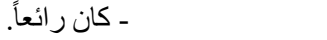 \\
\hline & 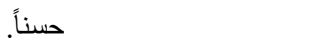 \\
\hline $\begin{array}{l}\text { All righty. } \\
\text { Is that all for you today then? }\end{array}$ & هل هذه كل حاجياتكك البوم إذن؟ \\
\hline
\end{tabular}

Now the task of subtitler becomes more complicated with the pronoun 'you' which is problematic in the TL more than in the SL, as it can refer to duality and plurality (plurality as in French Tu and vous). In the following excerpt, the estate agent Casey is showing the couple their new house:

\begin{tabular}{|c|c|}
\hline [11] ST: & TT: \\
\hline Hi, you must be Casey? & نعم، أنا كايسي. مرحباً. \\
\hline Yes, I am. Hello. & ـ كيف حالك؟ سايمون. \\
\hline $\begin{array}{l}\text {-How you doing? Simon. } \\
\text {-Hi, Simon. }\end{array}$ & معذرة لأننا جعلناك تنتظرين. اسمها روبين. \\
\hline $\begin{array}{l}\text { My wife, Robyn. } \\
\text { Sorry we kept you waiting. }\end{array}$ & \\
\hline
\end{tabular}

As seen in the above example, exophora in the use of 'you' can refer to elements outside the text and can be ambiguous, and in this case there is the issue of duality; this can only be clear when examining the intersemiotic element (visual signs made by the actors). This issue can be seen in example [1] earlier, where the Arabic 'you' is the 'أنتما' [you both].

4.4 Lexical cohesion

Equivalence at the lexical level is also a problem in translation in general and in AVT in particular. Making sense of 
homonyms such as the word 'too' which means 'also' and 'very', and the word 'window' (see below), will be important in order to grasp the use the most relevant meaning in context. Here is a conversation between the cashier in a supermarket and the husband,

\begin{tabular}{|c|c|}
\hline [12] ST: & TT: \\
\hline $\begin{array}{l}\text { Except for one thing my wife's } \\
\text { gonna bring down soon, I hope. }\end{array}$ & 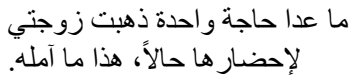 \\
\hline $\begin{array}{l}\text { No problem. I'll just look } \\
\text { for a delivery date then. }\end{array}$ & من من من مشدلة. سأبحث \\
\hline $\begin{array}{l}\text { Yeah, please, and it's the end } \\
\text { of today too ambitious? }\end{array}$ & هي مو عد طموح يصعب تحقيقة وهلية اليوج \\
\hline $\begin{array}{l}\text {-It's late, isn't it? } \\
\text {-Yeah, our truck already passed. }\end{array}$ & ـ ـ ـعم، سبق أن غادرت شاحنتنا. \\
\hline $\begin{array}{l}\text { Tomorrow work? } \\
\text { I have a window from, like, } 7 \text { to } 9 ?\end{array}$ & عندي وقت مثلاً من 7 إلى 9-؟ \\
\hline
\end{tabular}

Another interesting example of lexical cohesion is this:

\begin{tabular}{|c|c|}
\hline [13] ST: & TT: \\
\hline Hi. Hi. & مرحباً. مرحباً. \\
\hline You're a natural. & أنت أم بطبيعتك. \\
\hline -Do you want one? & 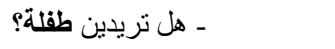 \\
\hline -Yeah. & 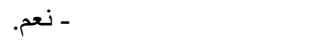 \\
\hline We're trying. & 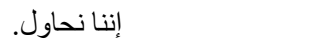 \\
\hline $\begin{array}{l}\text { I was pregnant, actually, } \\
\text { last year, in Chicago. }\end{array}$ & السنة الماضبية في شيكاغو، في الحقيقة، \\
\hline It wasn't a very happy ending. & لم تكن نهاية الحمل سعيدة. \\
\hline Sent me into a bit of a rough patch. & بعدها مررت بفترة صعبة قليلاً. \\
\hline $\begin{array}{l}\text { I will bore you } \\
\text { with the details another time. }\end{array}$ & سأخبرك بالتفاصيل المملة \\
\hline
\end{tabular}

Making sense is important in coherence, as in the word 'natural' below used as a noun and not as an adjective, to mean 'motherly by nature'. There is a context of situation, 'you are a mother by nature'; also, 'one' is a pro-form and a homonym, the same spelling but two different meanings. Here the word 'one' clearly refers to the number one, meaning 'one baby'. Another issue is related to the sentence 'sent me into a bit of a rough patch' with the ellipsis of subject, 'pregnancy/miscarriage'.

A further example of lexical cohesion relating the meaning of a word and its TL equivalent is the following, where it is required to have a translation shift in form of changing the word class of the SL word to a different one in the TL. Choosing the meaning of the SL word 'wrong' is always problematic and is often mistakenly translated literally into the TL (Arabic) when in fact translation shift is required at the word class level, from an adjective to a verb, see below:

[14] ST: $\quad$ TT:

Hey. Thank you for the lovely gift.

That was very sweet

but I'm sure that you spoke to Simon about that.

Well, he might have left me a message.

$$
\begin{aligned}
& \text { بالمناسبة، شكر اً للك على الهدية الجميلة. } \\
& \text { كانت تلك حلوة جداً } \\
& \text { لكني متأكدة من أنك تكلمت } \\
& \text { مع سايمون عنها. } \\
& \text { للحقيقة، ربما ترك لي رسالة صوتية. } \\
& \text { للحقيقة، ربما أخطأنا }
\end{aligned}
$$


'Wrong' is an adjective in the SL. It is noticeable that literal translation of this particular word is problematic in the TL, so a translation shift, i.e. a shift of the word class to that of a verb instead of the adjective, will solve this problem.

A further lexical cohesion example is to making sense of an ambiguous expression 'be out like a light':

\begin{tabular}{|c|c|}
\hline [15] ST: & TT: \\
\hline $\begin{array}{l}\text { I was very excited to share it } \\
\text { with you last night }\end{array}$ & 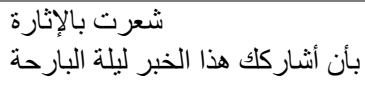 \\
\hline when we got home. & حينما عدنا إلى البيت. \\
\hline But you were out like a light. & لكنك نمت مباشرة. \\
\hline
\end{tabular}

Here 'you were out like a light' means in this context 'you fell fast asleep', which cannot be translated literally due to the fact that it is an expression in the SL.

Making sense is an issue, particularly when there is a fixed expression like 'to bury the hatchet' (the idiomatic language or a fixed expression in the SL needs to be taken care of; as the literal translation would not make sense and therefore affect the coherence - the object and action concepts and their relations). One needs to remember that non-sensical text is non-communicative, if the expression is translated literally it would be senseless:

\begin{tabular}{|c|c|}
\hline \multirow{2}{*}{$\begin{array}{l}\text { [16] ST: } \\
\text { I wanted to apologize. }\end{array}$} & TT: \\
\hline & أردت أن أعتذر. \\
\hline Robyn and I were talkin & كنا أنا وروبين قد تكلمنا... \\
\hline $\begin{array}{l}\text {...things that happened } \\
\text { back at school. }\end{array}$ & .... عن الأمور التي حدثت \\
\hline $\begin{array}{l}\text { About how I might not } \\
\text { have treated you so well }\end{array}$ & عن مسألة أني ربما لم أعاملك \\
\hline $\begin{array}{l}\text { and she wanted me } \\
\text { to bury the hatchet. }\end{array}$ & إصلاح الأمر بيننا. \\
\hline $\begin{array}{l}\text { Or as you said, } \\
\text { let bygones be bygones. }\end{array}$ & 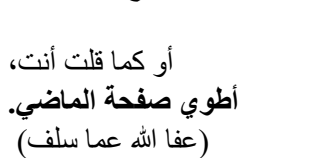 \\
\hline
\end{tabular}

Finally, a culture specific item in the SL might be problematic in the TL when trying to produce its cultural equivalence, as in the case of the word 'congratulations':

\begin{tabular}{|c|c|}
\hline [17] ST: & TT: \\
\hline I came to say... & جئت لكي أقول... \\
\hline ...congratulations. & ... ألف مبروك. \\
\hline
\end{tabular}

The cultural expression in the TL is 'a thousand congratulations'. Also, تهانينا [our congratulations] is also appropriate.

4.5 Intentionality and acceptability

Intentionality can be seen in the register as in the example [11] above about the use of formal or informal language as in the salutation 'hi' and 'hello'. But a better example where the wife Robyn is intentionally using a different register (formal language) to that of the visitor who is a friend of her husband Gordon; the latter is using the informal language:

\begin{tabular}{|c|c|}
\hline [18] ST: & TT: \\
\hline $\begin{array}{l}\text {-Hi. } \\
\text {-Hello. -Uh, Gordo. } \\
\text {-Oh, yeah, yeah, yes. Gordo, hi. }\end{array}$ & - مـ - مرحباً. \\
\hline $\begin{array}{l}\text {-Hi. } \\
\text {-Hey, Gordo, how are you? }\end{array}$ & ـ ـ نعم، نعم، نعم. غوردو ، أهلا. \\
\hline -It's nice to see you. & ـ أنت يا غوردو ، كيف حالك؟؟ \\
\hline
\end{tabular}


-Oh, hello.

-Hi. How you doing?

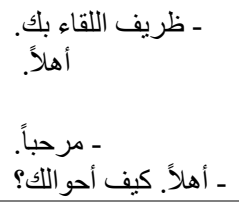

Again formality and informality to achieve the text producer's intention are issues to consider. In Arabic two completely different words are used as equivalents of 'hi' and 'hello', but both are still formal, so translation loss occurs but is compensated by the use of the two different lexical items. It is worth-noting in this example the verb 'doing' means to ask about 'How are you?', and is not the pro-verb 'do' discussed earlier.

It is worth comparing examples [11] and [18] with the following one:

Intentionality is felt in the register, the use of informal language between the two characters as text producers and text receivers at the same time. Both the text producer and text receiver in [19] use the same level of informality in SL, as it is the husband and wife talking to each other. In the TL however, this is rather difficult to achieve as colloquial language is only used and acceptable sometimes in dubbed films but not in subtitling.

A further point in this example [19] is about the deictic or 'pointing word' here, the word 'that' and the pro-form, the pronoun 'it', and they refer to the gift which was a bottle, a drink. This is yet another example of exophora.

Another interesting example where cohesion and coherence are reduced and tolerated for the purpose of intentionality is when Gordon tries to introduce himself to the couple by drawing the attention of the husband Simon, whom he believes to be his school peer:

\begin{tabular}{|c|c|}
\hline [20] ST: & TT: \\
\hline $\begin{array}{l}\text {-Hey, excuse me. Hi. } \\
\text {-Hi. }\end{array}$ & ـ ـ أنت، اعذرني. مرحباً. \\
\hline $\begin{array}{l}\text { I am sorry to bother you. } \\
\text { I'm-- I think I know you. }\end{array}$ & أنا... أعتقد أني أعرفك. لمعذ. \\
\hline $\begin{array}{l}\text { Yeah? I'm sorry, I don't-- } \\
\text { Can't place you. }\end{array}$ & نعج؟ معذرة، أنا لا... \\
\hline
\end{tabular}

It is interesting here to see that 'I'm' and 'I don't' are even reduced further in their TL equivalents '.... أنا ، ... У' [I no...], the TT is shorter, respects the TL grammar but still give the same effect as that of the ST.

A further occasion of intentionality is where intentionality is no longer accepted by the text receiver; but the text producer insists on having 'good intentions':

\begin{tabular}{|c|c|}
\hline [21] ST: & TT: \\
\hline & "ملاحظة: و أعتذر بشأن العشاء. \\
\hline $\begin{array}{l}\text { "P.S. I also apologize } \\
\text { about the dinner. }\end{array}$ & دون الدخول في التفاصبل، \\
\hline Without going into detail, & بأن تشاهدا المكان الذي أسكن فيه. أنقال أنقر \\
\hline $\begin{array}{l}\text { I think I would feel ashamed } \\
\text { to have you see where I really live. }\end{array}$ & لا أعيش منلكما تماماً قصة النجاح \\
\hline $\begin{array}{l}\text { I am not exactly the success story } \\
\text { that you both are. }\end{array}$ & إني غبي." \\
\hline
\end{tabular}


Stupid me."

No, another sad face.

Two sad faces.

Turn it over. There's more.

"P.P.S. Simon, after all these years,

I really was willing

to let bygones be bygones.

I had nothing but good intentions."
لا، وجه حزين آخر.

وجهان حزينان.

إقلب الصفحة. ثمة المزيد.

"ملاحظة أخرى،

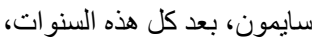

كنت ر اغباً في

أن أطوي صفحة الماضي.

ما كانت عندي سوى نوايا حسنة."

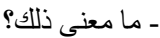

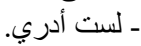

حقاً؟

للحقيقة، لا بـ أنه يعني شيئاً.

Really?

Well, it must mean something.

Text receivers, both of them, are not sure what the message means. Again they are having difficulty in accepting the intentionality of the text producer in the letter he sent to the couple. Also there is an item in the above example [21] about lexical cohesion, and the meaning of a cultural item, whose equivalent is 'to forget the past'.

\subsection{Intertextuality}

Having a previous text or texts within the current text is recurrent in films; for instance the previous text can be seen in calling their friend Gordo instead of his full first name Gordon, e.g.

\begin{tabular}{|c|c|}
\hline [22] ST: & TT: \\
\hline This is my wife, Robyn. This is-- & هذه زوجتي، روبين. و هذا... \\
\hline I didn't catch your name, sorry. & لم أذكر اسمك، معذرة. \\
\hline $\begin{array}{l}\text {-Ah, Gordon Mosely. } \\
\text {-Hi. Gordon. }\end{array}$ & - ـ ـ غوردباً. غوردن. \\
\hline -Gordo? & ـ - غوردو؟ \\
\hline -Robyn. & - روبين. \\
\hline
\end{tabular}

The person is called Gordon, but the short form is used in the past when the two mates Simon and Gordon were at school, but now they are middle aged. Another point is the use of the short form of the name later on in the film; this becomes intentional to despise him (Gordon). So intentionality is touched upon in various places in the film.

Also, intertextuality is seen in the use of a culture-specific item such as the common expression 'Simon says', e.g.

\begin{tabular}{|c|c|}
\hline [23] ST: & TT: \\
\hline He had a very organized campaign, & كان يقوم بحملة منظمة للغاية، \\
\hline Simon says. & بعنو ان "قال سايمون". \\
\hline Like the children's game. & مثل لعبة الأطفال، "قالت العصفورة". \\
\hline Well, his campaign & للحقيقة، كانت حملته \\
\hline was based around the game, & تعتمد على تللك اللعبة. \\
\hline $\begin{array}{l}\text { so Simon says, } \\
\text { and it would happen. }\end{array}$ & إذاً يقول سايمون، \\
\hline
\end{tabular}

Here the character is called Simon and there is the children's game known by that clause, so addition is required in the following subtitle. So its most common equivalent in the TL needs to be inserted at some point to show this element. Therefore, addition is needed to say قالت العصفورة] the little bird tells me or the little bird says]. This addition is done for the purpose of explaining the pun used by Gordon (the text producer) for the wife Robyn (the text receiver).

قالت لي ' Here is another example, again playing on words or phrases 'Simon says' with its Arabic idiomatic expression العصفورة'; a heavily loaded cultural equivalent here which has been used only once to show the pun. 
Right? Simon says, "Beautiful wife."

صحيح؟ قال سايمون، "زوجة جميلة".

And "a new home." Well, see?

Should have no problems

starting a family.

و "بيت جديد". للحقيقة، ترين؟

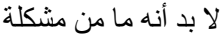

Because it's Simon says.

في تكوين عائلة.

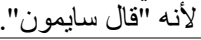

Another reference to culture which can be considered intertextuality is the following:

[25] ST: TT:

Do you have a baby?

No. No.

У.

Just the dog, for now,

"Mr. Bojangles," after the song.

الكلب وحسب، في الوقت الحالي.

"السيد بوجانغلز" تيمنا باسم الاغنية.

Intertextuality here refers to the name of the dog and also to the singer and his song called Bojangles.

Finally, previous texts can even occur in the same current text as in the well-known expression 'let bygone be bygone':

\begin{tabular}{|c|c|}
\hline [26] ST: & TT: \\
\hline You could ask him more about it. & كان عمري 12. ما أخبرني أحد أب شيء، \\
\hline & لكن با صديقتي، كانت عاصفة كبيرة \\
\hline but man, it was a big storm & في بلدة صغيرة إنّ صح التعبير ، لعلمك؟ \\
\hline in like a small town, you know? & "أطوي صفحة الماضي" \\
\hline BYGONES BE BYGONES & \\
\hline
\end{tabular}

Another marginal issue is writing in uppercase in the SL. This style is not used in the TL so adding inverted commas could be the solution.

\subsection{Informativity}

Playing with high and low informativity can be problematic in translation, particulary as the latter creates a boring response by the text receiver, and the element of surprise is created in the former. This is where downgrading and upgrading techniques are required by text users (producers and receivers), downgrading high order of informativity and upgrading a low order or level of informativity. Here is Simon being the text producer telling his wife the text receiver how long Gordon and he knew each other:

\begin{tabular}{|c|c|}
\hline [27] ST: & TT: \\
\hline $\begin{array}{l}\text { Gordon Mosely. } \\
\text { Oh, my gosh, honey. }\end{array}$ & غوردن موسلي. \\
\hline $\begin{array}{l}\text { Gordo and I } \\
\text { went to school together like... }\end{array}$ & في نفس المدرسة قبل... \\
\hline $\begin{array}{l}\text {-I don't know, what, } 80 \text { years ago? } \\
\text {-Oh, really? Oh, my God. }\end{array}$ & ـ لا أعرف، قبل 80 سنة؟؟ \\
\hline $\begin{array}{l}\text {-Almost. } \\
\text {-Wow. }\end{array}$ & ـ ـ رائع. \\
\hline $\begin{array}{l}\text {-Sorry, excuse me, I just-- } \\
\text {-You look very different. }\end{array}$ & ـ ـ عفو اً، اعذرني، كنت علتيّ نمامًا.. \\
\hline
\end{tabular}

A further evidence is this informativity standard is the unexpected information in the following example, since informativity is about expected and unexpected information, or known and unknown information. The dialogue below is between Simon's sister and Robyn, where Simon's sister Joan (Robyn's sister in law) who was attending the same school as Simon her brother talks about how long one incident in the school has taken place:

\begin{tabular}{|c|c|}
\hline [28] ST: & TT: \\
\hline $\begin{array}{l}\text { Hey Joan, do you remember } \\
\text { a guy called Gordon Mosely? }\end{array}$ & رجلاً اسمّه غوان، هل تذكرين موسلي؟ \\
\hline Gordo? & 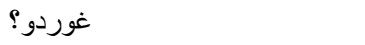 \\
\hline $\begin{array}{l}\text { He was at high school } \\
\text { with you and Simon? }\end{array}$ & كان في الثانو ية معك ومع سايمون؟ \\
\hline $\begin{array}{l}\text { Yeah. Yeah, no, Gordo. } \\
\text { He was the kid that got sent away. }\end{array}$ & كان الؤلد الذّي تم طردمد. \\
\hline
\end{tabular}


Man, it was like a million years ago

but they found him getting molested in a car by this older kid.

كان ذلك قبل مليون سنة

لكنهم عثروا عليه في سيارة

كانت يتحرشه ولد أكبر مثنه سناً.

We trust that the above examples in AVT have provided ample demonstrations for the application of the seven standards of textuality. The table below is a concise guide for audiovisual translator (whether dubber or subtitler) to facilitate decision making during the process of their work:

Table of recommended rules in AVT

\begin{tabular}{|c|c|c|}
\hline Feature & ST & TT \\
\hline $\begin{array}{l}\text { Cohesion } \\
\text { Ellipsis of subject, verb, phrase }\end{array}$ & Missing items/words & $\begin{array}{l}\text { Short replacement of these } \\
\text { items/words }\end{array}$ \\
\hline Pro-verbs & $\begin{array}{l}\text { The verb 'do' as main verb (and not } \\
\text { as auxiliary or modal verb) in the } \\
\text { sentence is a recurrent feature }\end{array}$ & $\begin{array}{l}\text { The closest equivalent is a proper } \\
\text { verb }\end{array}$ \\
\hline Pro-forms (e.g. pronouns) & $\begin{array}{l}\text { Exophora, anaphora and cataphora } \\
\text { are heavily used }\end{array}$ & $\begin{array}{l}\text { TL equivalence should clearly be } \\
\text { defined in terms of gender } \\
\text { (masculine and feminine for both } \\
\text { animate and inanimate objects) and } \\
\text { duality as opposed to plurality; and } \\
\text { ensure that the TL grammar is } \\
\text { respected with regard to subject- } \\
\text { verb agreement or adjective-noun } \\
\text { agreement. }\end{array}$ \\
\hline Lexical cohesion (making sense) & $\begin{array}{l}\text { Collocations, idioms and fixed } \\
\text { expressions }\end{array}$ & $\begin{array}{l}\text { Avoid literal meaning, i.e. } \\
\text { dictionary entry words/items }\end{array}$ \\
\hline Intertextuality & $\begin{array}{l}\text { Culture-specific items heavily } \\
\text { loaded from previous texts included } \\
\text { in the current text }\end{array}$ & $\begin{array}{l}\text { Equivalents should imply a link } \\
\text { between previous texts/experiences } \\
\text { with current text/experience }\end{array}$ \\
\hline Informativity & Low or high informativity & $\begin{array}{l}\text { Keep to the same level of } \\
\text { informativity in the TL but keep an } \\
\text { eye on the effect of this device as it } \\
\text { can be used in humour. }\end{array}$ \\
\hline
\end{tabular}

\section{Conclusion}

It has become apparent that actors/characters in AV environment are the ones who swap roles, alternating between being text producers and text receivers who respond only when communication occurs. Having many text producers and text receivers in the original (AV) script makes the task of translating their production (text) challenging and very interesting, because the final product should be rendered in such a way that it is communicative, its knowledge or content/sense is activatable and recoverable by and easily accessible to the target language users. In order to make the translation task manageable, it is vital to break it down into easy-to-handle stages through following de Beaugrande's seven standards of textuality.

Now it has been concluded that while these seven standards of textuality have been of great contribution to solving problems, this single approach, however, is not adequate in solving all English Arabic translation issues encountered in this paper, in particular AVT. An eclectic theoretical approach is therefore certainly required to solve all AV EnglishArabic problems. A table has been suggested as an aid to the translator/subtitler/dubber.

It has also been concluded that cohesive devices in the SL are more recurrent in AVT than other devices. This is followed by intentionality and acceptability of both text producers and text receivers; then by intertextuality (referring back to previous texts within the current text such as 'Simon says', and 'let bygone be bygone') which holds the third rank in the number of its recurrent textual features. Finally, informativity seems to be least used in this film.

\section{References}

Al-kadi, T. (2010). Issues in the subtitling and dubbing of English-language films into Arabic: Problems and solutions, $\mathrm{PhD}$ thesis submitted to University of Durham.

Brown, G., \& G. Yule. (1983). Discourse analysis. Cambridge: Cambridge University Press.

Carstens, W.A.M. (1997). Afrikaanse tekslinguistiek. In Inleiding. (Afrikaans text linguistics. An Introduction.) Pretoria: JL van Schaik Akademies.

Chaume, F. (2010). Audiovisual Translation: Dubbing. London \& New York: Routledge. 
Chiaro, D. Ed. (2010). Translation, humour and the media. London: Continuum International Publishing Group.

Crystal, D. (1992). An encyclopedic dictionary of language and languages. Oxford: Basil Blackwell.

De Beaugrande, R.A. (1995). Text linguistics. In: Verschueren, J. e.a. (eds.) 1995. Handbook of pragmatics, Manual. Amsterdam/Philadelphia: John Benjamins. pp. 536-544.

De Beaugrande, R.A., \& Dressler, W.U. (1981). Introduction to text linguistics. London: Longman.

Díaz Cintas, J. (1996). Teaching and learning to subtitle in an academic environment. in The didactics of audiovisual translation. Jorge Díaz Cintas (ed.), Amsterdam / Philadelphia: John Benjamins Publishing Company.

Díaz Cintas, J. (2009). New trends in audiovisual translation. Bristol, Buffalo and Toronto: Multilingual Matters.

Díaz Cintas, J., A. Matamala And J. Neves, E. (2010). New insights into audiovisual translation and media accessibility. Amsterdam \& New York: Rodopi.

Donnelly, C. (1994). Linguistics for writers. Buffalo: SUNY Press.

Gamal, M. Y. (2008). Egypt's audiovisual translation scene. In Arab media \& society. The Middle East Centre, St. Antony's College, University of Oxford: 1-15. http://www.arabmediasociety.com/articles/downloads/20080510203556 AMS5 Muhammad Gamal.pdf

Gary, N. (1976). A discourse analysis of certain root transformations in English. Reproduced by the Indiana University Linguistics Club: Bloomington, Indiana.

Halliday, M.A.K., \& Hasan, R. (1976). Cohesion in English. London: Longman.

Hatch, E. (1992). Discourse and language education. Cambridge/New York: Cambridge University Press.

Hussain, A. E. And Khuddro, A. (2016). English Arabic cultural effect in translation: A relevance theory perspective, 4(1), 31-44.

Hussain, A. E. And Khuddro, A. (2016). Quest for truth - New linguistic research methodologies. British Journal of English Linguistics (BJEL), 4(1),19-35.

Jackson, H. (1990). Grammar and meaning: A semantic approach to English grammar. London/New York: Longman.

Khuddro, A. (1993). Poems by Philip Larkin translated into Arabic. Al-Arbi'āiyyūn Journal, 4(3), 170-181.

Khuddro, A. (1997). Media translation. Turjuman. 6(2), 115-30.

Khuddro, A. (2000). Subtitling in Arabic. Turjuman. 9(1), 31-37.

Khuddro, A. (2009). Subtitling triangle: Technique and practice. In Translating Voices for Audiovisuals, ed. by Federico M. Federici, 209-18. Rome: ARACNE editrice S.R.L.

Khuddro, A. (2013). Arabic/English syntax in Translation: At word and sentence levels. Rome: ARACNE Editrice S.R.L.

Luyken, G.M, Herbst, T., Langham-Brown, J., Reid, H., And Spinhof, H. (1991). Overcoming language barriers in television: Dubbing and subtitling for the European audience, Manchester: European Institute for the Media.

Mccarthy, M. (1991). Discourse analysis for language teachers. Cambridge: Cambridge University Press.

Neubert, A., \& Shreve G. (1992). Translation as text. Kent, OH: Kent State University Press.

Renkema, J. (1993). Discourse studies. An introductory textbook. Amsterdam/Philadelphia: John Benjamins.

Schiffrin, D. (1994). Approaches to discourse. Oxford: Basil Blackwell.

Tannen, D. (ed.) .(1982). Analyzing discourse: Text and talk. Washington, D.C.: Georgetown University Press.

Tannen, D. (1984. Conversational style: Analyzing talk among friends. Norwood, N.J.: Ablex.

Tannen, D. (1994). Gender and discourse. Oxford/New York: Oxford University Press. Trask, R.L. 1995. Language: The Basics. London/New York: Routledge.

Van dijk, T.A. (1972). Some aspects of text grammars: A study in theoretical linguistics and poetics. The Hague: Mouton.

Van dijk, T.A. (ed.) 1985a/b/c/d. Handbook of discourse analysis. Vols. I, II, II, IV: Disciplines of Discourse. London: Academic Press.

Werlich, E. (1976). A text grammar of English. Heidelberg: Quelle \& Meyer. 